J. Perinat. Med. 17 (1989) 107

\section{Influence of delivery on plasminogen activator inhibitor activity}

\author{
Heinz Koelbl ${ }^{1}$, Johannes Kirchheimer ${ }^{2}$, and Gerhart Tatra' \\ ${ }^{1}$ 2nd Department of Obstetrics and Gynecology and ${ }^{2}$ Laboratory for Clinical- \\ Experimental Physiology at the Department of Medical Physiology, University of \\ Vienna, Austria
}

\section{Introduction}

Plasminogen activators are serine proteases which initiate the fibrinolytic system by conversion of the proenzyme plasminogen to the active fibrin degrading enzyme plasmin. Two different types of plasminogen activators have been characterized: A urokinase-type plasminogen activator (u-PA) is produced and secreted by several cells and found in different body fluids. Tissue-type plasminogen activator (t-PA) is mainly responsible for activating the fibrinolytic defence system against thrombosis. Plasminogen activator inhibitors (PAI) found in endothelial cells and the placenta inhibit the effects of both plasminogen activators [18]. Changes of plasma concentrations of plasminogen activators and their inhibitors are found under various physiological and pathophysiological conditions. Hypoxia, venous occlusion, vein thrombosis, prostaglandines and histamine cause an alteration of plasma t-PA antigen levels $[10,12,21$, 24]. An increase of u-PA was found in patients with malignant disease and inflammations [13, 24]. PAI changes were observed in patients with venous thrombosis, malignant disease, myocardial infarction and are released by endotoxins and stress [6, $10,21,25]$.

Uncomplicated pregnancies are accompanied by hypercoagulability and an increased risk of thromboembolic disease. Thrombosis is rare in the first trimester and most events are noted in the last trimester.

In this study we measured plasma levels of plasminogen activators and their inhibitors in women with uncomplicated pregnancy near term and after delivery.

\section{Curriculum vitae}

HeINZ Koelbl, $M . D$. , was born in 1957 in Vienna, Austria. He studied medicine at Vienna University, Austria. After graduation in 1981, he specialized in obstetrics and gynecology in 1983. Since then he is resident at the Second Department of Obstetrics and Gynecology, University of Vienna. His scientific fields

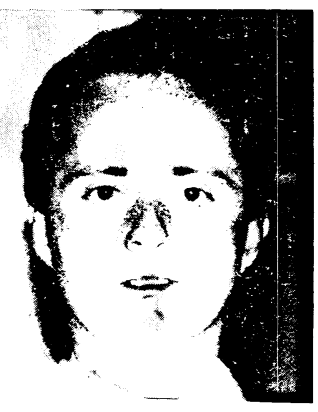

are gynecology and oncology.

\section{Patients and methods}

Fourty-four healthy women (age, mean \pm SD: $24.3 \pm 4.3$ yrs) with uncomplicated full term pregnancies were studied. The timing of the blood samples was as follows: (1) before the onset of labour without rupture of the foetal membranes and without uterine contractions, (2) from the first to the fifth day after delivery. Blood samples (10 $\mathrm{ml}$ ) were collected with ethylenediaminetetraacetic acid (EDTA, $5 \mathrm{mM}$ ) as anticoagulant, by venipuncture from the antecubital vein with minimal venous occlusion. Platelet-poor plasma was obtained immediately by centrifugation at $2000 \mathrm{~g}$ for $20 \mathrm{~min}$ at $4^{\circ} \mathrm{C}$. Aliquots for the respective determination were stored at $-70^{\circ} \mathrm{C}$ until used.

\subsection{Determination of u-PA antigen}

Urokinase antigen levels were determined in plasma using a competitive radioimmunoassay 
for high molecular weight urokinase [9]. All determinations were done in triplicate. The lower detection limit was $50 \mathrm{pg}$ urokinase antigen $/ \mathrm{ml}$, the intraassay variation was approximately $4 \%$ and the interassay variation approximately $6 \%$ [8].

\subsection{Determination of t-PA antigen}

T-PA antigen was determined with a sandwich ELISA employing two monoclonal antibodies against human t-PA $[5,20,26]$. All determinations were done in duplicate. The lower detection limit of the assay was $0.5 \mathrm{ng} / \mathrm{ml}$, the intraassay variation $5 \%$ and the interassay variation $10 \%$ [26]. The value obtained correlated with a sandwich ELISA using a polyclonal and a monoclonal antibody also developed in our laboratory [15].

\subsection{Determination of PAI activity}

Determination of PAI activity was performed using a functional assay measuring the inhibition rate of purified single chain t-PA by plasma samples as published previously [14, 23]. The PAI assay used in this study is a functional assay incapable of distinguishing immunologically distinct PAIs derived from different sources i.e. placenta, vascular endothelium or platelets [27]. The intraassay coefficient of variation was $8 \%$ and the interassay coefficient of variation was $11 \%$ [14].

\subsection{Statistical analysis}

Mean values and the SD of the plasma levels of the different parameters were calculated from all values obtained before and after delivery. Significant differences in the plasma levels of the different observations and respective age-matched control patients [11] were calculated using Wilcoxon test for unpaired observations. Significance was assigned for $p<0.05$. Linear correlations were calculated between the values of the different components of the fibrinolytic system for each time separately and between these parameters.

\section{Results}

The plasma levels of u-PA antigen, t-PA antigen and PAI activity of 44 healthy women before and after delivery were compared with the values obtained from the age-matched healthy control group (table).

Before the onset of labour no significant difference was found for u-PA and t-PA antigen in comparison to an age-matched control group. In the puerperium the mean plasma antigen levels of both plasminogen activators remained unchanged. In addition, no influence of birth weight and placental weight was found on t-PA and u-PA plasma levels $(\mathrm{p}>0.05)$.

Compared to an age-matched, non-pregnant control group a significant increase of PAI activity was found in women before delivery $(p<0.005)$.

Table. Means \pm SD for fibrinolytic parameters before and after delivery of 44 pregnant women and the agematched control group

\begin{tabular}{lllc}
\hline & $\begin{array}{l}\mathrm{u}-\mathrm{PA} \\
(\mathrm{ng} / \mathrm{ml})\end{array}$ & $\begin{array}{l}\mathrm{t}-\mathrm{PA} \\
(\mathrm{ng} / \mathrm{ml})\end{array}$ & $\begin{array}{l}\text { PAI } \\
(\mathrm{U} / \mathrm{ml})\end{array}$ \\
\hline control group & $6.91 \pm 0.82$ & $6.05 \pm 1.90$ & $8.30 \pm 3.94$ \\
before delivery & $6.71 \pm 1.85$ & $7.84 \pm 2.81$ & $12.13 \pm 4.79$ \\
day 1 p.p. & $6.37 \pm 0.89$ & $7.47 \pm 3.49$ & $8.13 \pm 1.97$ \\
day 2 p.p. & $6.83 \pm 0.78$ & $5.60 \pm 2.41$ & $7.99 \pm 2.49$ \\
day 3 p.p. & $6.97 \pm 1.12$ & $7.11 \pm 1.42$ & $8.79 \pm 1.78$ \\
day 4 p.p. & $6.61 \pm 1.44$ & $7.01 \pm 2.21$ & $8.32 \pm 2.71$ \\
day 5 p.p. & $6.39 \pm 0.87$ & $5.85 \pm 2.83$ & $8.22 \pm 2.09$ \\
\hline
\end{tabular}

*...p $<0.005$ 
However, one day after delivery the PAI activity levels were significantly lower than during the last period of pregnancy $(p<0.005)$. Compared to the control group no significant difference was observed for PAI activity one day post partum and levels remained unchanged until the fifth day after delivery.

\section{Discussion}

Our results show, that t-PA antigen levels at the end of pregnancy are the same as in non pregnant women. We think that the high level of PAI is responsible for the depressed fibrinolytic activity at the end of pregnancy [1]. These findings are in contrast to those of Kruithof et al., who observed an increase of u-PA and t-PA of $50 \%$ and $200 \%$, respectively [16].

We found a significant increase of PAI activity in pregnant women near term. This observation is in accordance to reduced fibrinolytic activity during pregnancy as described by Astedt [4] and Stirling [22]. In addition, Gore [8] found significantly increased levels of a fast-acting tissue plasminogen activator inhibitor throughout pregnancy.

Furthermore, we observed a significant decrease of PAI activity at the first day after delivery. These observations are in accordance to those of Lecander [17], who isolated a specific plasminogen activator inhibitor with a molecular weight of 70.000 daltons, increasing successively during pregnancy and falling sharply after delivery.

Our data indicate that this decrease in PAI might be caused by removal of the placenta. Recently the localisation of a placental type plasminogen activator inhibitor in the trophoblastic epithelium was demonstrated by Astedt [2] using immunohistochemical methods. Whereas the localization in the trophoblast does not clearly indicate that these cells are the source of placental PAI a purely storage function is not excluded by the authors. The trophoblastic epithelial cells are in direct contact with the maternal blood and a passage of the protein into the maternal circulation is discussable [3].

The placenta has been estimated to be the most likely source of a pregnancy plasma plasminogen activator inhibitor as described by Lecander [17]. The rapid disappearance of this pregnancy-specific PAI is suggested by a short half-life. Compared to non pregnant women similar PAI activity was measured in the blood samples collected in the puerperium. Probably release of maternal production of normal non-pregnancy PAI is responsible for PAI activity present after delivery as reported by Mackinnon [19].

In conclusion, an increased PAI activity seems to be responsible for depressed fibrinolytic activity during pregnancy with a subsequent decline to normal range at 24 hours after delivery, obviously caused by the removal of the placenta.

\section{Summary}

Plasminogen activators initiate the fibrinolytic system by conversion of the proenzyme plasminogen to the active fibrin degrading enzyme plasmin. Plasminogen activator inhibitors inhibit the effects of both plasminogen activators. Uncomplicated pregnancies are accompanied by hypercoagulability and an increased risk of thromboembolic disease. Thrombosis is rare in the first trimester and most events are noted in the last trimester. Therfore, we studied the fibrinolytic system at the end of pregnancy and in the puerperium. Plasma concentrations of urokinase plasminogen activator (u-PA/competitive radioimmunoassay), tissue type plasminogen activator (t-PA/sandwich ELISA) and plasminogen acti-

vator inhibitor (PAI/functional assay) were determined in 44 women (age: $24.3 \pm 4.3$ years) with normal pregnancy near term. Plasma samples were collected before the onset of labour and 1, 2, 3, 4 and 5 days after delivery. Compared with an age-matched non pregnant control group $(8.3 \pm 3.94 \mathrm{U} / \mathrm{ml})$ significantly increased PAI activity $(12.13 \pm 4.79 \mathrm{U} / \mathrm{ml}-\mathrm{p}<0.005)$ was measured before delivery with a subsequent significant decrease $(8.13 \pm 1.97 \mathrm{U} / \mathrm{ml})$ to normal values on day 1 after delivery; plasma u-PA and t-PA antigen levels remained unchanged. Placental weight and birth weight had no influence on plasma levels of both plasminogen activators.

Keywords: Plasminogen activators, plasminogen activator inhibitor, pregnancy, puerperium. 


\section{Zusammenfassung}

Der Einfluß der Geburt auf die Aktivität des Plasminogenaktivatorinhibitors

Das fibrinolytische System wird durch Plasminogenaktivatoren, die die Umwandlung des Proenzyms Plasminogen in das Enzym Plasmin bewirken, in Gang gebracht. Plasminogenaktivator-Inhibitoren hemmen die Wirkung beider Plasminogenaktivatoren. Unkomplizierte Schwangerschaften sind von einem Zustand der Hyperkoagulabilität und einem erhöhten Thromboserisiko begleitet. Letzteres ist selten im ersten Trimenon und die meisten thromboembolischen Komplikationen werden im dritten Trimenon beobachtet. Dies war Anlaß, das fibrinolytische System am Ende der Schwangerschaft und im Wochenbett zu untersuchen. Plasmakonzentrationen von Urokinase-Typ Plasminogenaktivator (u-PA/kompetitiver Radio-immunoassay), Gewebe-Typ Plasminogenaktivator (t-PA/sandwich ELISA) und Plas-
minogenaktivator-Inhibitor (PAI/funktioneller Test) wurden bei 44 Frauen (Alter: $24.3 \pm 4.3$ Jahre) mit normaler und nahezu ausgetragener Schwangerschaft bestimmt. Plasmaproben wurden vor der Geburt und am 1., 2., 3., 4. und 5. Tag post partum gewonnen. Gegenüber einer altersentsprechenden nicht schwangeren Kontrollgruppe $(8.3 \pm 3.94 \mathrm{U} / \mathrm{ml})$ fanden wir einen signifikanten Anstieg der PAI-Aktivität (12.13 \pm 4.79 $\mathrm{U} / \mathrm{ml}-\mathrm{p}<0.005)$ vor der Geburt. Bereits am 1. Tag post partum kam es zu einem signifikanten Absinken der PAI Werte $(8.13 \pm 1.97 \mathrm{U} / \mathrm{ml})$ bis in den Normbereich. Plasma u-PA und t-PA Antigenspiegel zeigten gegenüber der Kontrollgruppe weder vor der Geburt noch im Wochenbett Veränderungen. Ein Zusammenhang zwischen Plazentagewicht, Geburtsgewicht und den Plasmakonzentrationen der Plasminogenaktivatoren war nicht herzustellen.

Schlüsselwörter: Plasminogenaktivatoren, Plasminogenaktivator-Inhibitor, Schwangerschaft, Wochenbett.

\begin{abstract}
Résumé
Influence de la naissance sur l'activité de l'inhibiteur des activateurs du plasminogène

Le système fibrinolytique est activé par les activateurs $\mathrm{du}$ plasminogène qui transforment la proenzyme plasminogène en enzyme plasmine. Les inhibiteurs des activateurs du plasminogène (PAI) inhibent les effets des deux activateurs du plasminogène. Les grossesses normales d'accompagnent d'une hypercoagulabilité et d'un risque de complications thromboemboliques. Les thromboses sont rares au premier trimestre, et fréquentes en fin de grôssesse. Pour cette raison, nous avons analysé le système fibrinolytique en fin de gestation et pendant la phase puerpérale. Les concentrations plasmatiques de l'activateur du plasminogène du type de l'urokinase (uPA/radioimmunoassay competitive), de l'activateur du plasminogène du type du tissue (t-PA/sandwich ELISA)
\end{abstract}

et du PAI (test functional) ont été déterminées chez 44 femmes (âge: 24,3 $\mp 4,3$ ans) avec une gestation normale, près de la délivrance. Des prélèvements ont été effectués avant le commencement des contractions et au 1 er, 2éme, 3éme, 4éme et 5éme jours post partum. Nous avons trouvé une activité du PAI significativement élevée $(12,13 \mp 4,79 \mathrm{U} / \mathrm{ml}-\mathrm{p}<0,005)$ avant la délivrance en comparaison d'un groupe controle, du même âge et non enceinte $(8,3 \mp 3,94 \mathrm{U} / \mathrm{ml})$. L'activité du PAI était redescendue aux valeurs normales au premier jour du post partum $(8,13 \mp 1,97 \mathrm{U} / \mathrm{ml})$. Les concentrations plasmatiques de l'u-PA et de t-PA ne changent pas avant ou après la délivrance. Les poids du placenta et du nouveau-né n'influencent pas les concentrations des deux activateurs du plasminogène.

Mots-clés: Activateurs du plasminogène, grossesse, inhibiteur des activateurs fu plasminogène, phase puerpérale.

\section{References}

[1] Astedt B, L Holmberg, IM NiLsSON: An inhibitor of t-PA in pregnant plasma. Haemostas 14 (1984) 101

[2] Astedt B, I HÄGERSTRAND, I LeCANDER: Cellular Localisation in placenta of placental type plasminogen activator inhibitor. Thromb Haemostas 56 (1986) 63

[3] Astedt B, I Lecander, T Brodin, A Lundblad, K Löw: Purification of a specific placental plasminogen activator inhibitor by monoclonal antibody and its complex formation with plasminogen activator. Thromb Haemostas 53 (1983) 122
[4] Astedt B, S Isacson, IM Nilsson: Fibrinolytic activity of veins during pregnancy. Acta Obstet Gynec Scand 49 (1970) 171

[5] BINDER BR, JS SpRagG, FK Austen: Purification and characterization of human vascular plasminogen activator derived from blood vessel perfusates. J Biol Chem 254 (1979) 1998

[6] Colucci M, JA Paramo, D Collen: Generation in plasma of a fast-acting inhibitor of plasminogen activator in response to endotoxin stimulation. $\mathbf{J}$ Clin Invest 75 (1985) 818 
[7] Deutsch DG, ET Mertz: Plasminogen. Purification from human plasma by affinity chromatography. Science 170 (1970) 1095

[8] Gore M, S Eldon, KF Trofatter, SJ SoONG, SV PIzzo: Pregnancy-induced changes in the fibrinolytic balance: Evidence for defective release of tissue plasminogen activator and increased levels of the fast-acting plasminogen activator inhibitor. Am J Obstet Gynecol 156 (1987) 674

[9] HUBER K, J KIRCHHEIMER, BR BindeR: Characterization of a specific anti-human urokinase antibody: development of a sensitive competition radioimmunoassay for urokinase antigen. J Lab Clin Med 103 (1984) 684

[10] Juhan-Vague I, B Moerman, F De Cock, MF Aillaud, D Collen: Plasma levels of a specific inhibitor of tissue-type plasminogen activator (and urokinase) in normal and pathological conditions. Thromb Res 33 (1984) 523

[11] KIRCHHEIMER JC, BR BINDER: Urokinase antigen in plasma: age and sex dependent variations. Thromb Res 36 (1984) 643

[12] Kluft C, JH Verheijen, FH Jie, DC Rijken, PE Preston, HM Sue-Ling, J Jespersen, AO Aasen: The postoperative fibrinolytic shutdown: a rapidly reverting acute phase pattern of the fast-acting inhibitor of tissue-type plasminogen activator after trauma. Scand J Clin Invest 45 (1985) 605

[13] Koelbl H, JC Kirchieimer, G TAtra, G Christ, BR BINDER: Increased plasma levels of urokinasetype plasminogen activator with endometrial and cervical cancer. Obstet Gynecol (1988) in press

[14] KorNINGER C, O WAGNER, BR BINDER: Tissue plasminogen activator inhibitor in human plasma: development of a functional assay system and demonstration of a correlating $\mathrm{Mr}=50.000$ antiactivator. J Lab Clin Med 105 (1985) 718

[15] Korninger C, W SPEISER, J WOJTA, BR Binder: Sandwich elisa for t-PA antigen emplyoing a monoclonal antibody. Thromb Res 41 (1986) 527

[16] Kruithof EKO, C Tran-Thang, A Gudinchet, J Hauert, G Nicoloso, C Genton, H Welti, F BACHMANN: Fibrinolysis in pregnancy: A study of plasminogen activator inhibitors. Blood 69 (1987) 460

[17] LECANDER I, B AsTEDT: Isolation of a new specific plasminogen activator inhibitor from pregnancy plasma. Brit J Haematol 62 (1986) 221
[18] Loskutoff DJ, T Ny, M SaWdey, D LaWrence: Fibrinolytic system of cultured endothelial cells: regulation by plasminogen activator inhibitor. $\mathrm{J}$ Cell Biochem 32 (1986) 273

[19] Macinnon S, ID Walker, JF Davidson, JJ WALKER: Plasma fibrinolysis during and after childbirth. Brit J Haematol 65 (1987) 339

[20] NifuWenhuizen W, JH Verheisen, A Vermond, TG CHANG: Plasminogen activation by tissue activator is accelerated in the presence of Fibrin(ogen) cynogen bromide fragment (FCB-2. Biochem Biophys Acta 755 (1983) 531

[21] Nilsson IM, H LuUngner, L Tengborn: Two different mechanisms in patients with venous thrombosis and defective fibrinolysis: low concentration of plasminogen activator or increased concentration of plasminogen activator inhibitor. Br Med J 290 (1985) 1453

[22] Stirling Y, L Woolf, WRS North, MJ SeghATCHIAN, TW MEADE: Haemostasis in normal pregnancy. Thromb Haemostas 52 (1984) 176

[23] WAGNER OF, BR BindER: Purification of an active plasminogen activator inhibitor immunologically related to the endothelial type plasminogen activator inhibitor from the conditioned media of a human melanoma cell line. J Biol Chem 261 (1986) 14474

[24] Wijngaards G, E Groeneveld: Temporarily increased inhibition by plasma of plasminogen activator activity in severely ill patients. Haemostasis 12 (1982) 571

[25] Wiman B, B LJunberg, J ChmielewsKa, G URden G, M BLOMBÄCK, H JoHNSSON: The role of the fibrinolytic system in deep vein thrombosis. J Lab Clin Med 105 (1985) 265

[26] Wojta J, L Turcu, O Wagner, C Korninger, BR BINDER: Evaluation of fibrinolytic capacity by a combined assay system for t-PA antibodies. $\mathrm{J}$ Lab Clin Med 109 (1987) 665

[27] WUN TC, E REICH: An inhibitor of plasminogen activation from human placenta. J Biol Chem 262 (1986) 3646

Received August 10, 1988. Accepted January 24, 1989.

Dr. Heinz Koelbl

II. Universitäts-Frauenklinik

Allg. Krankenhaus d. Stadt Wien

Spitalgasse 23

A-1090 Wien, Austria 